Authors: Wanning Sun

Article Title:

Dark intimacy and the moral economy of sex: Rural migrants and the cultural politics of transgression

Journal Title: China Information: a journal on contemporary China studies

Date: 01 Jan 2021

Copyright $\odot 2021$ Sage Publications

Reprinted by permission of SAGE Publications.

Online version available on the SAGE Journals website

https://journals.sagepub.com/doi/10.1177/0920203X20963802 


\title{
Dark intimacy and the moral economy of sex: Rural migrants and the cultural politics of transgression
}

\author{
Wanning Sun \\ University of Technology Sydney
}

\begin{abstract}
It is difficult to conduct ethnographic inquiries into how China's rural migrant individuals make decisions about their bodies and their sexual capital, and to date there have been few attempts to do so. Equally scant are examinations of the moral, cultural, and political frameworks that rural migrant workers who live in poverty and in the socio-economic margins use to make sense of sexual decisions and choices. This article starts with an ethnographic glimpse into the lives of some sex workers in Shenzhen, and proceeds to analyse a range of texts: a novella, a novel, a cluster of news stories (from both commercial and state media), and a feature story in a popular lowbrow magazine. Pitting these texts against sex workers' own statements, as well as reading the texts in juxtaposition, brings into sharp relief the contradictions, connections, and coalitions between a range of discursive positions. The analysis suggests that a critical socio-economic framework, rather than a normative framework of transgression, may get us closer to understanding the emotional consequences of inequality. The analysis also demonstrates that for investigations into how inequality shapes intimacy, cultural texts may contain useful ethnographic insights that complement more traditional ethnographic methods.
\end{abstract}

\section{Keywords}

rural migrants, dark intimacy, inequality, sexual decision-making, media, literature as ethnographic partner

\section{Corresponding author:}

Wanning Sun, Faculty of Arts and Social Sciences, University of Technology Sydney, PO Box 123, Broadway NSW 2007, Australia.

Email: wanning.sun@uts.edu.au

$\mathrm{HL}$ is a non-government organization (NGO) in Shenzhen, and its director BB and her colleagues provide practical and emotional support to jiejie (姐姐, literally meaning 'older sister') - their respectful way of referring to rural migrant women who work as sex workers. Jiejie are spread around the city, ranging from high-end exclusive clubs to hair salons, massage parlours, and street corners. Because prostitution is unlawful, the organization has trouble accessing sex workers - especially initially. BB told me that taxi drivers were valuable sources of information about their likely locations. Intriguingly, messages posted online by male clients warning about possible police raids also offered clues to where sex workers could be working. Although their intention is to help these women, BB's small team still has trouble gaining their trust. 'When we approach them, they usually don't believe us at first, thinking that we're either touting for business on behalf of hotels or recruiting them for pyramid marketing. Some even suspected that we were working undercover for the police.'

HL also aims to destigmatize sex work, and the NGO advocates a more tolerant understanding of the decisions and choices made by these migrant workers. As BB and her colleagues made clear, jiejie are often mothers and daughters, wives and girlfriends, and in most cases they opt to sell their bodies in order to provide for their children and ageing parents. Sometimes their husbands or boyfriends work as their pimps and protectors:

A husband and wife team is not uncommon. I often come across women who come back to work as jiejie after a period of time back in the village. They go back, get married, have a baby, leave the baby behind and come back. I know someone who returned to work as soon as her baby was one month old. She told me her family needed money quickly. ${ }^{1}$ 
To BB and her colleagues, the 'normalcy' of the jiejie phenomenon is evidenced by the fact that some of the jiejie with whom they talk to still believe in love and romance. As one of BB's colleagues observed,

Many of us dare not love once we are betrayed or cheated on, and one would imagine that jiejie are totally immune to falling in love, since many of them enter the trade following broken marriages, domestic violence, and sexual assaults. Sometimes they do fall in love, though, and some of them are incurably romantic. Others are still waiting to fall in love.

Another observation made by BB was that some jiejie have quite conservative and traditional ideas about sex:

You may think that because selling sex is their job, they would be much more open and casual about discussing sex. We've been surprised that this is not always so. When we want to talk about sexual hygiene and contraception and so on, some get really shy and can't bring themselves to participate. Some even say things like 'girls don't talk about this sort of thing'. ${ }^{2}$

BB believes the migrant women she has encountered tend to fall into one of two categories: those who are very scared of being caught for their transgressive activities, are ashamed of their occupation, and feel very guilty; and those who are strong and believe that they are doing nothing wrong, since they are working to earn money - just like anyone else. BB and her colleagues were keen to stress that very few migrant women who work as jiejie regard selling sex as a permanent profession; many of them also work intermittently in factories:

I've come across women who work day shifts in the factory but work as jiejie in the evening. I've also met women who start with factory work and then move on to sex work. And when business is slow in the sex trade due to police crackdowns or for other reasons, they may go back to factory work until business picks up. ${ }^{3}$

HL regularly compiles in-house booklets, including stories written by sex workers themselves, so other sex workers can share experiences, provide tips and advice about self-protection, and give each other moral and emotional support. These are valuable ethnographic materials about a group of people whose work and lives are otherwise hidden. BB shared with me a series of fieldwork notes that either record her own conversations with jiejie or are transcripts of statements from jiejie themselves statements that, once anonymized, were circulated via HL's WeChat subscription account. One statement documents the story of a 55-year-old rural migrant who had worked in the sex trade for 20 years. Sister Li was married with children, but her husband had no income and refused to share any household chores. 'We were too poor. So I had to get out and work.' Sister Li worked at a number of odd jobs before deciding to 'plunge into the sea' of sex work. Since then, she has experienced myriad misadventures, including being robbed, arrested by the police, intimidated by clients, and extorted by brothel owners. But she has no regrets:

If I hadn't decided to take the plunge, I would never have been able to build a house for my son to get married, and pay for my social welfare insurance. Starting from next year, I'll be eligible for the pension. I'll be going home to enjoy my retirement. ${ }^{4}$

For this jiejie, her decision to become a sex worker was purely rational - there was nothing immoral or shameful about it. Ah Mi, another sex worker, echoes this sentiment:

Every decision I've made, I've made it for the sake of my family. I don't steal, rob, or swindle money from people. I make money just like every other business person. So, I hope I'll be treated the same way as everyone else. At least this way, I can provide for my daughter, and I'm doing my bit to ensure my financial security when I'm old ... I have no regrets. ${ }^{5}$

Both Sister Li and Ah Mi are painfully aware of the social stigma attached to their work, which exposes them to myriad forms of abuse, violence, and exploitation. A lack of legal status means they are unable to go to the police when they are robbed, beaten up, or conned by clients. Whether their 
clients are white-collar professionals in the central business district or migrant men in the cheap salons near factories, they have to have their wits about them in order to protect themselves.

Despite such challenges, these workers are adamant that they deserve just as much respect as any other person who is prepared to do honest work for honest pay. Like Sister Li, many other jiejie also work to ensure that their children are clothed, fed, and educated, and that when their sons grow up, they will have enough money to find a wife. Feeling that they should not be cast in a criminal light, they frame their work in terms of unconditional maternal love for their children and family, and stress that their willingness to make sacrifices on behalf of their children makes them as morally commendable as any other selfless mother.

\section{Analytical questions and methodological pathways}

The sense of transgression and its likely consequences that jiejie have to reckon with points to the need to consider the cultural politics of this phenomenon. Understandings of sexual transgression are historically and culturally specific, and vary from one political/religious context to another. The basis on which behaviour is determined to be sexually transgressive can be legal (legitimate/illicit), social (normal/deviant), moral (acceptable/objectionable), or political (conforming/not conforming to state authority). The concept of transgression has always been central to philosophers and scholars of other disciplines. While many philosophers have written on transgression in contexts such as religion, culture, or political power, it is Michel Foucault who sees sexual experience as a central domain in which boundary-crossing - a paradigm of transgressive behaviour - occurs. Foucault sees subject formation as a process of 'construction' and 'deconstruction' through negotiating the boundary between 'self' and 'other'. For him, transgression, defined as the repeated crossing of boundaries, leads to a destabilized subject that is neither unified nor rational. In terms of sexuality, this dualism would be defined in terms of normative (procreative) sexuality versus deviant sexuality (homosexuality). ${ }^{6}$ Drawing on Foucault, and in dialogue with Mikhail Bakhtin's work on the carnivalesque, Peter Stallybrass and Allon White identify four domains of transgression: place, body, social identity, and subjectivity. ${ }^{7}$ They suggest that ordering and sense-making in each of these domains is governed by 'interrelating and dependent hierarchies of high and low'. ${ }^{8}$ The politics and poetics of transgression, they argue, is therefore not only about forming and maintaining these hierarchies, but also about the 'processes through which the low troubles the high'. ${ }^{9}$ Finally, they argue that, since 'what is socially peripheral may be symbolically central', ${ }^{10}$ transgression has become an important concept for understanding how liminal or minority experiences help to form larger sociocultural boundaries.

A growing body of recent China-focused ethnography appears to embody this kind of intellectual endeavour, although not all of this work explicitly addresses the theme of transgression or intimacy. This includes Sandra Hyde's ethnography in Southwest China, where she examines the cultural politics of HIV/AIDS across boundaries of various kinds, and in the negotiations between corporeal, material, and discursive spheres. ${ }^{11}$ It includes ethnographic research on sex work, ${ }^{12}$ queer voices, ${ }^{13}$ and intimate services provided by rural migrant men, ${ }^{14}$ much of which explores the interface between the personal/individual and state power/socio-economic forces in China. This article contributes to this body of work, offering an explicit analysis of how the poetics of transgression contributes to the cultural politics of inequality.

Just as jiejie must reckon with the social stigma of transgression, so too must they reckon with what I call 'dark intimacy'. If intimacy is an 'intrinsic good' that involves 'mutual trust' and 'caring attention', and 'typically evokes . . . intense, warm feelings', ${ }^{15}$ dark intimacy, as I define it, refers to those sexual relationships that (1) are intrinsically structured around an imbalance in power, either within the relationship or between the couple and their context; and that, as a result, (2) operate in ways that may lead to injury or threaten to diminish trust, respect, and dignity for one or both individuals. This power imbalance may derive from differences in gender, socio-economic status, and urban versus rural origin, or personal attributes such as beauty, personality, or sex appeal. The imbalance can effectively restructure intimacy to produce feelings of shame, humiliation, anger, and low self-esteem for those who are exploited in the relationship. I have chosen the term dark intimacy to highlight both its similarities to and differences from Eva Illouz's notion of 'cold intimacy', ${ }^{16}$ and the kinds of intimacy Viviana Zelizer characterizes as 'warm'. ${ }^{17}$ 
Cold intimacy can also follow the same logic of economic relations and exchange as dark intimacy, but as Illouz defines it, it is practised mostly by the middle classes and uses the language and techniques of therapy and other market repertoires. Central to this understanding of intimacy is the technique of communication, and the concept and practice of communication is seen as an essential aspect of the self. Rather than allowing a relationship to take its 'natural' course, cold intimacy subjects the relationship to a range of calculated and strategic interventions. Cold and warm intimacy share the goal of creating trust and security, whereas dark intimacy involves exploitation and the abuse of power in unequal relationships, or potentially risky but mutually accepted transactional exchanges driven more by socio-economic and other external factors than by the desire to create a trusting and secure relationship. Dark intimacy may thus involve two consenting individuals and may sometimes possess the strategic nature of cold intimacy, but it rarely involves pursuing an enduring and mutually respectful relationship, which is the overriding concern of both cold and warm intimacy.

In exchanges involving dark intimacy, one or both individuals can often expect to experience a high level of humiliation, shame, anger, and despair: intimate encounters coloured by a power imbalance bring with them the risk of injury, pain, and damage. But there are connections as well as differences between these conceptions of intimacy, and they exist on a continuum rather than as binary opposites. Furthermore, just as warm intimacy, considered to be an intrinsic good, is unevenly distributed, so too is dark intimacy, considered an 'intrinsic bad', differentially distributed, usually based on social markers such as race, gender, and class. ${ }^{18}$ Studying the commercialization of intimacy, Arlie Hochschild observes that people occupying different socio-economic positions have different emotional experiences, inhabit different emotional worlds, and may even have different emotional ontologies. ${ }^{19}$ Given this, it is worthwhile studying how gender and class affect not only one's chances of enjoying warm intimacy, but also one's capacity to avoid dark intimacy.

The statements of the jiejie in the previous section reinforce these sociologists' observation that intrinsic goods such as warm intimacy are distributed unevenly across class and gender, but they further remind us that the discursive resources available to construct the meanings of intimacy are also unevenly distributed. While there is little public understanding of the socio-economic circumstances that propel rural migrant women into the sex industry, there is an abundance of widely circulated public narratives about rural migrants' sex lives, including migrant men pursuing sex and migrant women providing it, with both activities occurring in the grey zone of illicitness.

The account given by HL and the statements from the jiejie that HL supports give us a rare glimpse into how poor or socio-economically marginalized individuals make decisions about their bodies and their sexual capital. But how are their decisions represented in public discourses, and how is their sexual intimacy constructed by someone other than themselves? What moral, cultural, and political frameworks do they use to make sense of their sexual choices, and to what extent do these frameworks resonate with the jiejie's own perspectives? Answering these questions may yield important clues about the cultural politics of inequality, given that socio-economic inequality goes hand in hand with the unequal distribution of discursive resources,${ }^{20}$ and that any intellectual critique of inequality must address both the material and symbolic dimensions of the se two forms of inequality, as well as the interplay between them.

Recognizing the difficulty of generating data about emotions, and about sexual intimacy in general, both anthropologists like Judith Farquhar and sociologists like Illouz ${ }^{21}$ turn to fictional accounts and media texts. Farquhar considers works of literature to be 'wonderful anthropological partners' ${ }^{22}$ and believes that self-health publications in China offer considerable 'ethnographic riches' ${ }^{23}$ In this article I, too, turn to a range of texts: a novella, a novel, a cluster of news stories (from both commercial and state media), and a feature story in a popular lowbrow magazine in the genre of reportage. These fictional and media texts are useful for at least two reasons. First, as Farquhar suggests, writers - both fictional and journalistic - are our research partners, in whose works we can mine ethnographic insights even though we know that the texts cannot substitute for ethnographic fieldwork data. Second, and perhaps more pertinent to the central concern of this article, these texts target audiences that are segmented along lines of class, gender, and the rural-urban divide; they are also published within various business models, and push diverse political-cultural agendas. Juxtaposing them brings into sharp relief the possible contradictions, connections, and coalitions between several discursive positions, thereby helping to reveal the nuance and complexity of the cultural politics of inequality. 
Below, I first discuss how state and commercial media responded to the controversy of some Foxconn factory workers who were moonlighting as sex workers. This is followed by a section that pits jiejie in Shenzhen against a rural woman whose experience was reported in the popular Chinese magazine Soulmate (知音). Then, shifting to the perspective of migrant men, I explore how the sexual economy in China's industrial zone reshapes the masculinity of men at the bottom of the social hierarchy, taking as my starting point two key literary texts: The Sound of a Cleaver Sharpening in a

Rented Room (出租屋里的磨刀声, hereafter The Sound) and Loach (泥鳅). What connects and gives coherence to these cases is their capacity, when analysed in conjunction with one another, to reveal traces of 'the proliferation of distinctions, practices, stories, and moral injunctions concerning the interplay of economic transactions and intimacy'. ${ }^{24}$ Through the prism of these discrete cases, I aim to address some key questions raised earlier: what are the practical, material, and economic circumstances in which rural migrants make decisions about sexual intimacy?; what moral-economic grammar propels their decision-making?; what perspectives and discursive positions are used to construct narratives about them?; and what are the relationships and connections between these various discursive positions?

\section{Foxconn, 'factory girls', and state-capital complicity}

Economic Weekly (财经天下) is one of China's most influential and widely read publications, focusing on economic and business matters. Since its inception in 2012, it has enjoyed credibility in the business sector as well as among ordinary readers. On 9 September 2013, the magazine featured a leading story entitled 'Foxconn's night life'. ${ }^{25}$ Appearing without a byline, the 8000 -word article claimed to be an honest account of what life was like for Foxconn workers away from the factory shop floor, in the commercial and recreational spaces outside the industrial complexes in Shenzhen and Zhengzhou.

Drawing on interviews with individual workers, one section of the article landed the Economic Weekly in controversy. Subtitled 'Factory workers as part-time sex workers', this section began: 'In a place where tens of thousands of people in their early twenties concentrate, love and sex are unavoidable subjects'. According to the story, the budget hotels near the Foxconn industrial precinct do a roaring trade, especially on weekends, with lovers seeking some much-anticipated intimacy. Night clubs and disco dance halls are also portrayed as good places to meet someone for sex. Workers interviewed by the unnamed journalist seemed blasé about casual sex. Based on this journalist's observations, gynaecological clinics are located next to night clubs - clinics of dubious credibility advertising 'abortions without pain'. Equally noticeable are myriad brothels camouflaged as '10-bob massage parlours' and beauty salons.

While none of this would come as a surprise to most people, the story nevertheless made a claim that captured the public's imagination: that some women factory workers also sell sex for additional income. A young Shenzhen factory worker and part-time sex worker disclosed to the journalist that she knew a 'considerable number of women in her factory' who were part-time sex workers, explaining that 'when you put more than 100,000 single men and women together, sex is bound to happen. Since it's bound to happen, you might as well tap into this need and make some money. It all comes down to money.' According to this young woman, some women end up quitting factory work to become full-time sex workers. When asked whether she regretted having taken this step, one woman answered, 'My only regret is that I hadn't thought of doing this earlier.' She felt that she should have taken advantage of her youth and made more money so she could go back home and start a small business sooner.

The Economic Weekly's exposé of the sex trade among Foxconn workers was immediately reposted as many as 300 times. In order to attract attention, some websites reframed the article with a more sensational title, such as 'Foxconn's part-time sex workers: Their only regret is not having done it sooner'; 'Sex services provided by Foxconn workers: Their own account'; and 'Foxconn workers sell sex at RMB 300 each time'.

On 13 September, four days after the Economic Weekly article was published, the Foxconn Workers' Union issued a public protest via its microblog. The protest described the article as 'dark, 
and in poor taste', and calling its use of dirty and denigrating language an insult to the 400,000 women workers at Foxconn, who were 'hard-working, dedicated, and have made a contribution to China's manufacturing sector'. The Workers' Union demanded that the magazine withdraw the article and issue a public apology to Foxconn workers. The union also published a longer blog further interrogating the Economic Weekly's credibility, highlighting the story's failure to include the perspective of Foxconn management, criticizing the fact that the story was written by a cadet journalist, and castigating the Weekly for its erroneous apportioning of blame to Foxconn for the structural social problems that had arisen from China's rapid social transformation.

A week after the controversy had erupted, on 25 September, China Women's News (中国妇女报), the official newspaper of the All-China Women's Federation (中华全国妇女联合会, hereafter Women's Federation), weighed in on the debate by publishing a bylined commentary entitled 'It is worth paying more attention to women workers' inner world'. The article pointed out that although a small number of Foxconn workers did engage in 'illegal activities', it was wrong to regard all women workers at Foxconn through a tainted lens: 'Behind this war of words are the real lives of many dagong [打工, meaning 'working for a boss'] - migrant worker - individuals who live with uncertainty and a sense of loss of purpose'. Adopting a seemingly non-partisan stance, China Women's News apportioned blame to each side. It criticized the Economic Weekly - as well as many websites that reposted the article with a more sensational title - for pandering to 'voyeurism' and for irresponsibly catering to low tastes. It clearly did not agree with the Weekly's argument that some migrant women were simply making an economically rationalist decision by shifting from assemblyline work to sex work. And while it acknowledged the Foxconn Workers' Union for defending the workers, it pointed out that protesting in words was not enough, arguing that the union should take concrete action to give dignity to its workers. It also gave Foxconn's management a good dressing down for its failure to 'own up to its responsibilities, urging the organization to upgrade its production structure and improve working conditions for its workers'. ${ }^{26}$

To anyone untutored in labour politics in China, the Workers' Union appears to be the most logical spokesman for Foxconn's workers. But research by labour sociologists ${ }^{27}$ makes it clear that that is not so. The union has consistently remained silent on a wide range of crucial issues, including workers' wages, compensation for work-related injuries, suicides, working conditions, and living standards. The Foxconn Workers' Union consistently sides with management, and its role in the controversy concerning sex workers is at best ineffectual, at worst hypocritical.

If the China Women's News article gives the impression that the party-state, as represented by the Women's Federation and its official publication, is critical of transnational capital, a longer feature article in the China Women's News more than a month later confirms that there are indeed considerable complicity and moral coalition between Women's Federation and Foxconn. In contrast to the 'dark' and voyeuristic tone of the Economic Weekly, this second China Women's News feature, about the lives of Foxconn women workers in Zhengzhou, is full of optimism. Certainly, life is hard and work on the assembly line is 'repetitive', but workers 'face the challenges head on, and are rewarded with warmth and happiness'. They forge friendships with and lend support to each other, and learn to get along with co-workers on the assembly lines and in the dormitories, with 'understanding and mutual respect'. The article suggests that Foxconn is also the birthplace of many love stories, with many couples having found a 'harbour where they can rest and nurture their hearts'. Both the local government (through the local Women's Federation branch) and Foxconn's management are reported as playing a caring and enabling role. Equally notably, Foxconn is depicted as a place of hope, where workers learn new skills, acquire useful knowledge and experience, and, for those who apply themselves, have opportunities for promotion. Everyone dreams of making enough money to buy a house and start a family. Workers exemplifying 'positive' attitudes are quoted as saying that they were deeply hurt by the denigrating reporting on Foxconn women. While a small number of people 'could not resist temptation and had gone down the wrong path', the majority of Foxconn's women workers were becoming 'mature' and were as 'hardy and resilient as the plum flowers blossoming in winter' ${ }^{28}$

The story in the China Women's News clarifies the moral and political boundaries separating the legal from the illicit, the desirable from the objectionable, and implies that those who pursue this 
dream are morally superior. The article concurs with the Foxconn Workers' Union in saying that the Economic Weekly article was demeaning to Foxconn's women workers because it implies that it is shameful and morally unacceptable to sell sex to alleviate poverty. However, there is also an important divergence. The union wanted to gloss over the imperfections and defend all Foxconn women workers, whereas the China Women's News story acknowledges the existence of a 'minority of women' who engage in 'illegal practices' and who have 'gone down the wrong path' due to their moral weakness. In other words, the Women's Federation, and the government it represents, wants to endorse the moral virtue of the majority of workers, while aiming to 'separate the wheat from the chaff' by dividing them into 'the good' and 'the bad'.

Despite their divergences, both Foxconn and the Women's Federation adopt a legal and moral framework that is based on a transgressive versus normative dichotomy - a framework that is focused on governing and control. Sometimes at odds, but often complicit, the state, the market, and cultural/moral forces generally all shape public understandings of what is (un)desirable, (il)legitimate, and (un)acceptable in the sphere of sex and intimacy. These narratives, while differing in perspective, all insist on the binary division between the 'good girl' (who works on the assembly line despite longer hours and less pay than sex work) and the 'bad girl' (who transgresses moral boundaries, has no shame, and opts to sell sex for more and faster money). None of these narratives acknowledges the fact that, whether working on the assembly line or selling sex, migrant women's decisions are shaped by extrinsic forces that include state control, capital exploitation, and patriarchal practices. The war of words between Foxconn and the Women's Federation overlooks, or perhaps strategically ignores, the elephant in the room: transnational capital. Over a period of four decades, this force has securely installed a regime of industrial production and a way of life, both of which are dictated by and geared towards the logic of capital accumulation. This logic ensures that human interactions, including sex, love, and desire, have no alternative but to unfold in the capitalist nexus between power and money. While being a moral and ideological bedfellow of both the Foxconn Workers' Union and the organization's management, the party-state is at the same time a stakeholder in the regime of transnational capital and, as a result, can only construct narratives that justify and normalize the logic of capital, rather than questioning or critiquing it.

\section{Soulmate: The moral grammar of a popular magazine}

Founded in 1985 with the humble sum of RMB 30,000 by the Women's Federation's branch in Hubei Province, Soulmate (知音) is a biweekly magazine. Its Chinese title means 'kindred spirits', 'soulmates', or 'bosom friends'. The magazine, specializing in long-form journalism on soft news topics such as family, friendships, and relationships, was an instant success, quickly reaching a circulation of 400,000. According to a 2014 figure, Soulmate boasts a circulation of six million, second only to Reader (读者), and is now ranked fifth globally in terms of circulation. ${ }^{29}$ It is very likely that some of the jiejie discussed earlier have at some stage been readers of Soulmate.

Soulmate publishes only true stories, even though they are told in a long-form narrative style, and its winning combination of sensational news content, fictional narrative formula, and melodramatic style has even given birth to a 'Soulmate genre'. Soulmate's recurring narratives revolve around individuals being thrown into life-changing situations, such as dire poverty, life-threatening illness, and debilitating accidents. A disproportionately highly percentage of human dramas revolve around individuals' acts of selflessness and sacrifice, when someone in the family suddenly needs an expensive operation or a kidney transplant. Unfolding against this background of life-changing situations are the perennial dramas that reveal humans' capacity for compassion, selflessness, and sacrifice, with themes of love lost, found, regained, or betrayed being played out in the retelling of these dramas.

It is clear that the misfortunes commonly experienced by people in the Soulmate stories are often symptomatic of China's 'compressed modernity' and the consequent widening of socio-economic inequality. For instance, the diagnosis of a terminal disease may plunge an ordinary family into debt, due to the withdrawal of state-provided health care for all citizens. Manslaughter could be the result of a jealous woman's discovery that her husband, having become rich overnight, has taken on mistresses. Thus, whether they are portrayed as embodying moral virtue or moral depravity, the characters in 
Soulmate are individuals who are caught up in, flounder, and in some cases dumped hard by the whirlwind of China's hurried and bumpy journey towards modernity. However, the readers of Soulmate are led to believe that fortunes and misfortunes in both money and love are a matter of luck, and that to keep misfortunes at bay they should learn a moral lesson from these stories, as a result of which they will ultimately be rewarded for being a 'good' person.

To some cultural elites, the phenomenal and sustained popularity of Soulmate is a cause for concern. To them, the magazine is proof that, by catering to the taste and sensibility of the lowest common denominator, commercial popular culture has monopolized the cultural field. ${ }^{30}$ Despite such criticisms, Soulmate has a strong pedagogic agenda. Each issue features three leading stories, prominently labelled 'recommended reading' in the table of contents; many of the stories are bookended with editorial comments urging readers to emulate the loyal, trustworthy, and selfless lovers, to learn a lesson from the mistakes and follies of those who have gone astray, and to condemn those who choose violent, unlawful, or immoral methods to resolve emotional conflicts. The magazine warrants careful analysis in that it is a mixture of positions: it outlines the socio-economic circumstances that propel a woman to make certain choices about her intimate life, but it is still couched within a moral framework of the good versus the bad man/woman. The boundaries of transgression remain intact, while the motivations behind each stories' protagonists are simultaneously traditional and neoliberal.

We now look more closely at the pedagogic agenda of the Soulmate genre, through a December 2014 story in the magazine. The article is intriguingly entitled "A legend about a "marriage for sale": Fast track to money while love awaits'. In April 2014, a 25-year-old woman named Zuo Xiaofang places a notice in the personal column of a local paper, offering to marry anyone for a fee of RMB 100,000 - a sum equivalent to the customary local marriage dowry. Xiaofang's offer is motivated by her desire to save her brother, who suffers from leukaemia and is in urgent need of money for a bone marrow transplant. While the advertisement is met with widespread derision, a 26-year-old man named Liu Zhi from the same township answers it. He has heard that Xiaofang is a kind-hearted woman, that she had lost her father at an early age and left home early to work as a dagongmei (打工 妹, meaning 'working girl') in order to support her mother. He has also heard that she has never had a boyfriend, but that she takes matters of the heart seriously.

Liu is moved by Xiaofang's devotion to her brother, and offers her the money in exchange for an opportunity to spend time with her and her family. Liu is not a wealthy man. He has saved a little but has to borrow the rest. He says that his only expectation is to get to know her. He promises he will not force Xiaofang to marry him, and is prepared to wait until both he and she feel certain that marriage is what they want. Writing from the perspective of an omniscient third person, the reporter says:

Xiaofang is deeply grateful, but she does not know what else to do except to make herself fall in love with Liu Zhi. She knows that the only way to repay Liu Zhi's kindness is for both to fall in love with each other within the shortest possible time. ${ }^{31}$

And fall in love they do, marrying soon after, and Xiaofang's brother, having survived chemotherapy and a bone barrow transplant, is soon discharged from hospital. The reporter is at pains to assure readers that the marriage is based on mutual understanding and admiration:

Liu could have insisted on getting married straight away, asserting his conjugal right as a husband-to-be [based on Xiaofang's offer], but he doesn't. Instead, he waits patiently, looking after Xiaofang and her brother in hospital, in the hope that by doing so she will get to know him and appreciate him, and will eventually, of her own volition, fall in love with him. ${ }^{32}$

Are we to read this as a romantic story, or does this couple embody the very antithesis of romance? More importantly, in what ways - if any - do Xiaofang and Liu Zhu embody exemplary moral virtues? After all, Xiaofang's offer of marriage in exchange for money seems downright mercenary to her fellow townsfolk, not to mention foolhardy. And Liu Zhu's decision to purchase an opportunity to win Xiaofang's heart seems an equally risky investment. One could be forgiven for a cynical response: Xiaofang may be a dutiful daughter and sister, and she apparently places more value on family than her own happiness; having very low expectations of marriage, she may not be concerned about 
forfeiting her chances of finding love, as long as she can make a difference to her own family. Similarly, Liu Zhi wants a wife and has the money to 'purchase' one, so why not embrace the offer when it arises?

Xiaofang's marriage-for-sale offer and Liu Zhi's willingness to go along with it may contravene modern ideas about love, in which free choice, equality, intimacy, and emotional fulfilment are foundational. Yet in this story it would be too simplistic to read the couple's actions as examples of feudalism and patriarchy. Faced with poverty and a terminal illness in the family, Xiaofang does not expect a handout from the government or the community, nor does she blame the system for having failed her and her family. Even when she feels she is at the end of her tether, she does not resort to illegal means of acquiring wealth, including prostitution. Instead, she maintains hope and actively seeks to change her own and her family's lives for the better. She is simultaneously an exemplar of the virtuous, self-sacrificing daughter promoted within the old feudal moral code, and - quite consistent with the contemporary ethos of neoliberal governmentality - a self-managing, selfenterprising subject, an individual who is able and willing to overcome her family crisis through her own devices. However, unlike her society's elites, who have more resources at their disposal, her capacity to be self-reliant and enterprising is very limited; she must achieve her goal by sacrificing her freedom to choose whom she marries and falls in love with.

Why should such a story be considered newsworthy? Why should Xiaofang's and Liu Zhi's choices receive any kind of validation? There is at least one clear take-home message from the story. If a woman in a socio-economically marginal position decides to marry for economic rather than romantic reasons, she should not be chastised for being pragmatic or not modern enough. While a few people in the highest echelons of Chinese society may base their love options on ideals of individual choice, freedom, and a high level of warm intimacy, the majority still cannot afford such 'luxury goods'. Just as class privilege is reflected in differentiated levels of consumption, so too does such privilege manifest itself as stratified access to love as a 'moral good' ${ }^{33}$ Indeed, Xiaofang's marriage as an economic transaction, made morally acceptable to her by her status as a part-feudal, partneoliberal consumer subject, is one of the few options individuals from the underclasses can afford. Given that genuine Cinderella-meets-Prince stories are the stuff of fiction, myriad self-arranged poverty-alleviation strategies through marriage may well be many women's only realistic option.

Also worth asking is why a purely pragmatic marriage arrangement is narrated here as a love story. Xiaofang and Liu Zhi may well grow to love each other, just as older generations did - by 'marrying first, and waiting for love to grow' (先结婚, 后恋爱), through familiarization. But instead of adopting this non-romantic but more plausible framework, which nevertheless involves some kind of 'love', the story wants readers to believe in the possibility of romantic love, even though Xiaofang and Liu Zhi's agreement comes across as the very antithesis of romantic love. To imagine Xiaofang and Liu Zhi getting to know each other reasonably well and ending up liking each other enough to want to marry is one thing. But to convince readers that Xiaofang succeeds in 'falling in love' with a person not of her own choice within the required time is quite another. Can falling in love be construed as a form of emotional labour, requiring, as Hochschild observes, such 'deep acting' that the self comes to believe in it? ${ }^{34}$

Readers are told emphatically that Liu Zhu will not want to consummate their marriage unless Xiaofang falls in love with him, and that Xiaofang wills herself to fall in love as soon as possible. However, nowhere does the reporter acknowledge that, as the modern ideology of romance has us believe, love is spontaneous and individualistic, that it cannot be bought, rushed, forced to happen, or derived from gratitude. By insisting that marriage-for-sale and genuine love can go hand in hand, Soulmate does not aim to produce a fantasy of social mobility; nevertheless, its ideological agenda is no less ambitious. The magazine wants readers to contemplate adopting a more practical and instrumental approach to love as a way of coping with life's difficulties and challenges; but it also wants readers to believe that the pursuit of this instrumental approach to love can be just as romantic.

\section{The sound of a cleaver sharpening in a rented room}

A fine-grained portrayal of dark intimacy and rural migrants is not complete unless it also discusses migrant men's sexuality. When the topic of sexual loneliness among rural migrant men is mentioned 
in policy discourses, it is often couched within the framework of social order and stability. The emotional experience of a large number of single, sexually repressed men outside the framework of criminality and transgression is seldom available in public discourse s. The following story, written by migrant-worker-turned-professional writer Wang Shiyue (aka Wang Shixiao), offers us a rare glimpse of this experience.

Wang Shiyue has published numerous prize-winning novels, but it was the publication of The Sound in $2001^{35}$ that established him as one of the earliest and most promising dagong writers in South China. Wang adopts a first-person narrative to tell the story of Tianyou, a rural migrant worker in a Taiwanese-owned factory in Shenzhen. Like many co-workers, Tianyou is content with having a bed in the company-provided dormitory, sharing the room with 11 other people, until he starts dating $\mathrm{He} \mathrm{Li}$, a worker from another factory. Tianyou rents a room far from the city, at a fraction of the cost of the dormitory, and for a brief period each weekend the lovers ensconce themselves in blissful intimacy, oblivious of the man who rents the room next door. Tianyou and his girlfriend want to be together, alone, in a space of their own, without being bothered by or bothering anyone else - a privilege taken for granted by most middle-class people. Their desire is desperate and intense precisely because this is not something they can enjoy on a routine basis. Many circumstances militate against them, including precarious living circumstances, job insecurity, bad labour conditions, and insufficient money for decent, convenient accommodation. While most middle-class individuals take their right to intimacy - either warm or cold - as a given, the precarity of rural migrants' existence makes their right to intimacy at best contingent, conditional, and vulnerable to violation and exploitation.

The couple gradually realize, with mounting fear and horror, that the man next door sharpens his cleaver whenever they make love. Their appetite for intimacy evaporates, and Tianyou is suddenly plagued with impotence. They are unable to afford a rental room elsewhere, so the girlfriend leaves Tianyou, saying, 'I went out with you because I wanted to feel safe and secure. But that place gives me the creeps and I now feel terrified.'

Abandoned by his girlfriend, Tianyou becomes depressed and distracted at work. One day he loses four fingers while operating a lathe. His boss accuses him of carelessness and refuses him compensation. Tianyou is enraged. Alone in his rented room, he is greeted by Hong, the woman who lives with his cleaver-sharpening neighbour. Tianyou flies into a rage at her: 'Now my girlfriend has left me, my body is deformed, and I've lost my job, all because of your stupid man!' Sensing Tianyou's seething resentment and empathetic to his situation, Hong visits one day and gives him a chance to 'get even'. 'Have me', she says, 'if that makes you feel better.' It is an offer that both surprises and appeases Tianyou, and the scene ends with Tianyou taking up her offer, thereby releasing - albeit temporarily - his sexual frustrations onto the body of the cleaver sharpener's wife.

Still, Tianyou cannot appease his anger. One day, consumed with blind rage, he bursts into the room next door, wildly wielding his own cleaver, and before he knows what he is doing, he cuts the man numerous times. Instead of fighting back, the man tells Tianyou his story. Apparently, he and Hong had been childhood lovers. Unable to gain their parents' approval, they left the village to work in the southern factories so they could be together. For years they stuck together, going through numerous abortions as they could not afford to have a child. Hong's luck then took a turn for the worse. She was sacked from her job, became an escort, and one day she was raped by her boss. Hong and her lover agreed, against their better judgement, that she would work as a prostitute for one year, then they would leave to start a new life elsewhere. But the man was tormented by the thought of his woman being with other men. The noises of the lovers next door made it even harder for him to dispel the demons in his head. But he was not a violent man, so to control his violent urges - towards his own wife, her boss, her clients, the world in general - he would shut himself in his room, sharpening his cleaver. The 'repetitive movement of sharpening the cleaver becomes an integral part of his life, and with this he is able to enter a state of non-existence'. Readers are also told that 'the knifesharpening man and Hong eventually leave the rental room and move on. Nobody knows where they have gone.' Yet each night, the sound of a cleaver being sharpened can still be heard, except that 'now, it is Tianyou who is sharpening the knife'. Having experienced both warm and dark intimacy, and by turns victim and perpetrator, Tianyou is, in Foucault's words, a 'destabilized subject' who cannot achieve stability, rationality, and internal unity. 
In contrast to the relatively comfortable lives of contemporary middle-class Chinese men, rural migrant men's existence is dominated by their inferior class position as unskilled labourers engaged in precarious work, as well as by their concomitant inability to provide a stable, secure home for their family, should they be fortunate enough to find a partner. For the two men in this story, capital is seen to have injured their male pride and rendered them impotent - both physically and metaphorically. If the cleaver-sharpening husband's sexual identity is threatened by the market, which purchases his wife's body, Tiayou's masculinity is also questioned because his position in the lowly, precarious, and cheap labour system gives little bargaining power in the market. The humiliation felt by these two men is a stark reminder that, as Chinese sociologist of gender Du Ping points out, while men are the beneficiaries of a patriarchal system, some are also oppressed by the social pressures and expectations that are shaped by class, the rural-urban divide, and persistent gender inequality. ${ }^{36}$

Hong, the migrant woman in this story, is a complex character who deserves careful analysis. Her decisions about what to do with her body regarding different men suggest that she is capable of both positive intimacy and transactional sex. The story's ending is indeed poignant. Like many young rural migrant women, Hong becomes a prostitute because, rather than give her body to capital by working in a factory, she wants to 'appropriate' her 'own surplus value' ${ }^{37}$ As a young woman she yearns for love and is willing to defy parental authority to pursue intimacy with her lover, but she soon realizes she cannot survive on love alone. A victim of sexual assault and violence, she nevertheless uses sex for a range of purposes, including making a living, and offering it as a moral compensation to her neighbour. Hong's moral-economic grammar revolves around utilizing her own body as a site of exchange and conflict resolution, rented out to mediate inequalities that are structured by class, gender, and the rural-urban divide. Hong emerges from the story as a victim of socio-economic exploitation and patriarchal oppression, but in the eyes of its author, her myriad sexually 'transgressive' decisions are not only morally blameless but also demonstrate a strong survival instinct and exemplary resilience - moral courage, if not superiority. Adopting a moral-economic grammar that highlights structural inequality, Wang's narrative of rural migrants' sexual decisions seems to depart from the judgmental discourse of transgression, and instead compels readers to appreciate their own socioeconomic circumstances. This is an important counterpoint to the dominant discourse of transgression - an indispensable piece in the jigsaw puzzle of the complex cultural politics of inequality in contemporary China.

\section{Loach}

While ample fictional accounts exist of rural migrant women as sex workers, ${ }^{38}$ there is little insight fictional, journalistic, or scholarly - into the roles that rural migrant men play in the intimacy market, although recent studies have begun to study this. ${ }^{39}$ In this context, You Fengwei's Loach, ${ }^{40}$ one of the earliest novel-length works focusing on the sexuality of rural migrant men as well as women, warrants closer examination. Narrating the virginity, chastity, lust, and sexual decisions of a group of rural migrant workers, the novel centres on the sexual adventures of Gui, a young rural man who now works as a removalist, casual labourer, kitchen hand, cleaner, and construction worker. Poor and humble as his status is, Gui - like the gamekeeper in Lady Chatterley's Lover - has one advantage: he is young and very good-looking. Readers learn that he resembles a younger version of Chow Yun-fat (a successful Hong Kong movie star). Gui's girlfriend from his village comes to join him in the city; however, constrained by traditional rural values of chastity and female modesty, she refuses to have sex with Gui, whom she loves, until they marry - no matter how much they may want each other.

Meanwhile, through the intervention of a friend, Gui becomes the housekeeper of a middle-aged woman, Gong Yu. Gong's husband is rich and powerful, with close connections to the city's government officials. He lives apart from his wife, and surrounds himself with younger and prettier women. As a trade-off, he provides well for his wife, giving her an extremely luxurious home to live in. Gong accepts this arrangement and lives a materially privileged but emotionally empty life. When Gui takes the job as Gong's housekeeper, he has no idea that his role is going to extend to that of 'lover boy' - he is hoping to lose his virginity with his girlfriend on their wedding night. Now living in a secluded mansion with lots of money at his disposal, Gui is grateful to his employer. He also finds her attractive, despite their age difference. After repeated attempts by Gong, the two eventually become lovers. 
In many ways, Loach reverses the mainstream narrative of migrant male sexuality, which equates the male migrant body with criminality, and instead turns it into a site of desire and eroticism. At the same time, the novel does not simply represent Gui's body as a passive object. Despite the stark inequality between them in terms of age and class, Gui is made to feel like an equal sexual partner. However, their blissful life as 'love birds' comes to an abrupt end when Gong's husband's scheming lands Gui in police custody and then prison for a crime he has not committed: he plants incriminating evidence on Gui for a crime he himself has committed, then flees town. Gong tries to argue for Gui's innocence, but in vain. The fantasy of their intimacy transcending social and economic differences dies, pointing to the tragedy - the impossibility - of negotiating an equal sexual relationship despite extreme socio-economic inequality. Any illusions of equality Gui and Gong may have entertained are instantly dashed when Gui's wrists are handcuffed. Meanwhile, Gui's former girlfriend, being unable to fend off sexual prowlers in the city, becomes distraught and ends up going mad.

This is a vivid example of how patriarchy joins forces with class domination to produce a domino effect: the rich city man leaves his wife for younger women; his rich wife makes a younger rural migrant man the object of her desire; the rural migrant man betrays his rural girlfriend, leaving her to a tragic end. Gong is 'ambiguously placed'41 in this narrative, like white women in the heyday of colonialism, who were 'not the hapless onlookers of empire' but were 'complicit both as colonizers and colonized, privileged and restricted, acted upon and acting'. ${ }^{42}$ Measured against the criteria of traditional patriarchal expectations regarding marriage, fidelity, and female chastity - expectations that are shared by the Women's Federation - both Gui and his middle-class lover in Loach are morally transgressive in more than one sense. Gui's rural migrant girlfriend is the only one who is bound by traditional sexual morality and refuses to have sex before marriage, yet she is punished by her descent into madness, rather than being rewarded for her chastity and constancy. To You Fengwei, this is a cautionary tale against cross-class, and therefore transgressive, intimacy. Such boundarycrossing intimacy is not only illusory, but the illusion can lead to disastrous consequences for both parties. This is where the novel departs from the moral narrative framework of transgression we have seen in the public statement from Foxconn's management, as well as in the China Women's News and Soulmate stories. The author wants us to think that the characters in the novel are morally blameless, and that the choices they make about when to have sex and whom to sleep with are either constrained or enabled by the dynamic interplay of gender, class, and political and socio-economic power. Readers are likely to finish the novel feeling that the only morally reprehensible person in the story is the rich woman's husband.

\section{From a moral to a socio-economic framework}

I have chosen examples from the media and popular culture for analysis, because I see them as jigsaw puzzle pieces that, when put together, conjure up a nuanced and complex - though not necessarily comprehensive - picture of the cultural politics of inequality. By asking how these narratives help to explain rural migrants' motivations and choices in entering into intimate transactions, we can see that transgression is a central theme circulating across a wide range of state-sponsored media narratives and statements from transnational capital. The Women's Federation's and Foxconn management's responses to rural migrant women workers selling sex adopt a normative perspective within which to criticize and condemn these individuals' sexual choices. Both organizations maintain a dichotomy between the docile body and the transgressive body, as well as a binarism between love and sex. This framework aims both to govern and to provide moral guidance. Others - such as the authors of The Sound and Loach - reveal both the inadequacy and political expediency of the framework, thereby initiating moral interventions within that framework. When juxtaposed, these narratives - both fictional and journalistic, both state-endorsed and market-driven - reveal the moral fault lines in the public discourse of sexuality.

This discussion points to an increasingly complex cultural field whereby the state, the market, and other social and political forces all shape public discourses of what is morally (un)desirable, (il)legitimate, and (un)acceptable. There is a coalition between state and capital that further reinforces the 'triple oppression' of migrant workers. ${ }^{43} \mathrm{~A}$ further complication is the ambiguous role of the government-sponsored commercial media, which sometimes challenge the government and transnational capital, but at other times are either complicit in their strategies of governing or exploit 
dark intimacy for the purpose of generating profits. The Women's Federation's response to the 'Foxconn factory girl' debate suggests that the state's position towards rural migrant women sex workers is founded on a moral boundary between the morally commendable dagongmei seeking love and the morally questionable woman who trades dignity and self-respect for quick and easy money. The position of the Women's Federation is couched in patriarchal values that, while criticizing women on moral grounds, nevertheless do not concern themselves with sexual exploitation, or with the use of sex as a site of economic exchange within marriage.

This discussion reveals the fraught nature of the dagongmei's intimate sexual practice. Most of the rural migrant women in these stories have, in various ways, done away with the vigilantly maintained dichotomy between the good and the morally transgressive. Whether it be the Foxconn assembly-line worker who sells sex to male workers, the woman who marries a stranger to raise money for her brother's medical costs (in Soulmate), or the jiejie who insist on pressing their claim for dignity and respect, these narratives invariably point to the complex and contradictory nature of these women's agency - an agency marked by a refusal to succumb to the state, patriarchy, and capitalist logic, and a capacity to enter the market as a calculative agent. However, a confluence of political, social, economic, and cultural forces is likely to drive them into various forms of dark intimacy that produce mostly negative feelings such as shame, anger, and injured dignity. Their actions and decisions on intimate matters make it necessary for all parties - the government, capital, subaltern writers, and feminist NGOs - to regroup and adjust, forming a new dynamics of political and ideological alignments and contestations.

The cases analysed in this article also reveal the complexity that marks rural migrant men's masculinity. These fictionalized yet rich and ethnographically significant accounts of men 'at the bottom' remind us that no man exists outside the power dynamics that result when class, gender, and rural-urban inequality intersect. ${ }^{44}$ The emotional pain and humiliation that are acutely familiar to both Gui in Loach and the knife-sharpener in The Sound demonstrate how patriarchy negotiates with political power and social structure to reshape rural migrant men's gender-based self-identification. Struggling at such an inhospitable nexus, migrant men also experience gender- and class-specific shame and humiliation.

By analysing these representations, I have demonstrated the political usefulness of an alternative strategy for seeking to explain subaltern sexual practices in China. I suggest that a critical socioeconomic framework, rather than a normative framework of transgression, may get us closer to understanding the emotional consequences of inequality. Such an approach is necessary because (1) a normative moral discourse of transgression sets up the dichotomy between love and money and sees intimacy and economic transactions as mutually exclusive or, at worst, mutually contaminating; and (2) the connection between sexual intimacy and economic transactions is natural and rational, ${ }^{45}$ as the experiences of migrant men and women in the stories suggest. Further, as the various cases discussed here show, it is socio-economic inequality, rather than a normative notion of moral competence, that shapes individuals' capacity to achieve dignity and respect and to enjoy those 'intense, warm feelings' that are typically expected from sexual intimacy. Finally, the framework of transgression, which often evokes law and order, stigmatizes and punishes migrant women who pursue sex to support their families. The actions of sex workers may be unlawful, yet the jiejie argue that if honest work for honest pay can confer dignity, then they deserve as much dignity and respect as every other working person. Conversely, as in the Soulmate story, the rural migrant woman's decision to marry the first man who is willing to pay her brother's medical bills, while falling within the moral boundaries of marriage, nevertheless raises questions about whether marriage itself can be regarded as a site of unequal socio-economic exchange.

This discussion also advances a methodological argument pertaining to the empirical status of ethnography, and asks what we should do in the absence of 'first-hand' data on dark intimacy. It is only with the help of 'second-hand' ethnography that I have been able to sketch the landscape of dark intimacy. Much of the ethnographic material presented here was produced by my 'surrogate ethnographers ${ }^{46}$ - writers, journalists, NGOs. Given that some of these narratives are fictional, I have presented them as unreliable yet crucially useful 'data'. I argue that, although some may doubt their empirical reliability, and although they certainly cannot replace fieldwork research data, they nevertheless add value of another kind to our intellectual inquiry, by revealing the contestation and complicity that exists between various storytellers. Thus, if we juxtapose, compare, and contrast these 
stories, and trace their differences/connections methodically in terms of perspective, frame, and discursive position, we may be able to 'get at' the cultural politics of inequality and its intimate consequences - an intellectual opportunity that exclusively fieldwork-based research does not usually offer.

\section{References}

Aying 阿颖 (2014) ‘婚姻收购'传奇: 金钱直达哟爱情缓存 (A legend about a 'marriage for sale': Fast track to money while love awaits). 知音 (Soulmate), no. 12, 36-8.

Bao, Hongwei (2018) Queer Comrades: Gay Identity and Tongzhi Activism in Postsocialist China. Copenhagen: NIAS Press.

Cartier, Carolyn (2001) Globalizing South China. Oxford: Blackwell.

Du, Ping 杜平 (2017) 男工·女工: 當代中國農民工的性別, 家庭與遷移 (Male workers, female workers: Gender, family, and migration of contemporary Chinese rural migrant workers). Hong Kong: 香港中文大學 出版社 (Chinese University of Hong Kong press).

Engebretsen, Elisabeth L. (2014) Queer Women in Urban China: An Ethnography. Abingdon, UK and New York: Routledge.

Farquhar, Judith (2002) Appetites: Food and Sex in Post-Socialist China. Durham, NC: Duke University Press.

Foucault, Michel (1977) Language, Counter-Memory, Practice: Selected Essays and Interviews. Ed. Bouchard, Donald F. Trans. Bouchard, Donald F. and Simon, Sherry. Ithaca, NY: Cornell University Press.

富士康的夜生活 (Foxconn's night life) (2013) 13 September. http://tech.sina.com.cn/it/2013-0913/09318736823.shtml, accessed 28 July 2020.

Hochschild, Arlie Russell (1983) The Managed Heart: Commercialization of Human Feeling. Berkeley: University of California Press.

Hochschild, Arlie Russell (2003) The Commercialization of Intimate Life: Notes from Home and Work. Berkeley: University of California Press.

Hyde, Sandra Teresa (2007) Eating Spring Rice: The Cultural Politics of AIDS in Southwest China. Berkeley: University of California Press.

Illouz, Eva (1997) Consuming the Romantic Utopia: Love and the Cultural Contradictions of Capitalism. Berkeley: University of California Press.

Illouz, Eva (2007) Cold Intimacies: The Making of Emotional Capitalism. Cambridge, UK: Polity Press.

Illouz, Eva (2012) Why Love Hurts: A Sociological Explanation. Cambridge, UK: Polity Press.

Jeffreys, Elaine and Su, Gang (2018) Governing HIV in China: Commercial Sex, Homosexuality and Rural-toUrban Migration. Abingdon, UK and New York: Routledge.

Kam, Lucetta Yip Lo (2013) Shanghai Lalas: Female Tongzhi Communities and Politics in Urban China. Hong Kong: Hong Kong University Press.

Kong, Travis S. K. (2011) Chinese Male Homosexualities: Memba, Tongzhi and Golden Boy. Abingdon, UK and New York: Routledge.

Liu, Tingting (2019) Wounded masculinities: The subaltern between online longings and offline realities. In: Sun, Wanning and Yang, Ling (eds) Love Stories in China: The Politics of Intimacy in the Twenty-First Century. Abingdon, UK and New York: Routledge, 113-30.

McClintock, Anne (1995) Imperial Leather: Race, Gender and Sexuality in the Colonial Contest. Abingdon, UK and New York: Routledge.

Pan, Suiming (2006) Transformations in the primary life cycle: The origins and nature of China's sexual revolution. In: Jeffreys, Elaine (ed.) Sex and Sexuality in China. Abingdon, UK and New York: Routledge, 21-42.

Pun, Ngai (2005) Made in China: Women Factory Workers in a Global Workplace. Durham, NC: Duke University Press.

Selden, Mark, et al. (2014) Worker-intellectual unity: Suicide, trans-border sociological intervention, and the Foxconn-Apple connection. Asia-Pacific Journal 12(11). https://apjjf.org/2014/12/11/PunNgai/4093/article.html, accessed 28 August 2020.

Stallybrass, Peter and White, Allon (1986) The Politics \& Poetics of Transgression. Ithaca, NY: Cornell University Press. 
Sun, Wanning (2013) Inequality and culture: A new pathway to understanding social inequality. In: Sun, Wanning and Guo, Yingjie (eds) Unequal China: The Political Economy and Cultural Politics of Inequality. Abingdon, UK and New York: Routledge, 27-42.

Sun, Wanning (2014) Subaltern China: Rural Migrants, Media, and Cultural Practices. Lanham, MD: Rowman \& Littlefield.

Tan, Chris K. K. and Xu, Zhiwei (2020) The 'social factory' of China's male 'virtual lovers'. In: Sun, Wanning and Yang, Ling (eds) Love Stories in China: The Politics of Intimacy in the Twenty-first Century. Abingdon, UK and New York: Routledge, 168-84.

Tao, Haiqing 陶海青 (2014) 知音传媒上市前景几何? (What is the prospect of going public for Soulmate Media?). 中 国 贸 易报 (China trade news), 12 June. http://www.chinatradenews.com.cn/epaper/content/2014-06/12/content_17897.htm, accessed 9 September 2020 .

Tsang, Eileen Yuk-ha (2020) Being bad to feel good: China's migrant men, displaced masculinity, and the commercial sex industry. Journal of Contemporary China 29(122): 221-37.

Wang, Shiyue 王十月 (2001) 出租屋里的磨刀声 (The sound of a cleaver sharpening in a rented room). 作品 (Literary works), no. 6, 4-10.

Yan, Dan 间丹 and Su, Jianjun 苏建军 (2013) 在压力中成长在迷茫中坚守的富士康女 (Foxconn women maturing under pressure and persevering under disorientation). 中国妇女报 (China women’s news), 6 November, A03.

Yao, Peng 姚鹏 (2013) 更值得爸注的是女工的内心世界 (It is worth paying more attention to women workers' inner world). 中国妇女报 (China women's news), 25 September, A02.

You, Fengwei 尤凤伟 (2002) 泥鳅 (Loach). Shenyang: 春风文艺出版社 (Chunfeng literature and art publishing house).

Zelizer, Viviana A. (2005) The Purchase of Intimacy. Princeton, NJ: Princeton University Press.

Zhang, Ning 张柠 (2013) 知音体与低端文化商品的生产和消费 (Soulmate genre and the production and consumption of low-end cultural products). http://blog.sina.com.cn/s/blog_a353266f0101rcrs.html, accessed 28 July 2020.

\section{Notes}

This work was supported by the Australian Research Council (grant no. DP1095380).

BB, personal interview, 23 October 2017. All names of NGOs and individuals in this article are anonymized. Ibid.

Ibid.

BB, personal interview, 2018. Although the WeChat subscription account's URL is available, I have decided to withhold it in order to protect the identities of the individuals concerned.

5 Ah Mi, personal interview, 2017.

6 Michel Foucault, Language, Counter-Memory, Practice: Selected Essays and Interviews, ed. Donald F. Bouchard, trans. Donald F. Bouchard and Sherry Simon, Ithaca, NY: Cornell University Press, 1977; see the chapter 'A preface to transgression', 29-52.

7 Peter Stallybrass and Allon White, The Politics \& Poetics of Transgression, Ithaca, NY: Cornell University Press, 1986.

8 Ibid., 2 .

9 Ibid., 3 .

10 Ibid., 23.

11 Sandra Teresa Hyde, Eating Spring Rice: The Cultural Politics of AIDS in Southwest China, Berkeley: University of California Press, 2007.

12 Pan Suiming, Transformations in the primary life cycle: The origins and nature of China's sexual revolution, in Elaine Jeffreys (ed.) Sex and Sexuality in China, Abingdon, UK and New York: Routledge, 2006, 21-42.

13 Travis S. K. Kong, Chinese Male Homosexualities: Memba, Tongzhi and Golden Boy, Abingdon, UK and New York: Routledge, 2011; Elisabeth L. Engebretsen, Queer Women in Urban China: An Ethnography, Abingdon, UK and New York: Routledge, 2014; Lucetta Yip Lo Kam, Shanghai Lalas: Female Tongzhi Communities and Politics in Urban China, Hong Kong: Hong Kong University Press, 2013; and Hongwei 
Bao, Queer Comrades: Gay Identity and Tongzhi Activism in Postsocialist China, Copenhagen: NIAS Press, 2018.

14 Eileen Yuk-ha Tsang, Being bad to feel good: China's migrant men, displaced masculinity, and the commercial sex industry, Journal of Contemporary China 29(122), 2020: 221-37; Tingting Liu, Wounded masculinities: The subaltern between online longings and offline realities, in Wanning Sun and Ling Yang (eds) Love Stories in China: The Politics of Intimacy in the Twenty-First Century, Abingdon, UK and New York: Routledge, 2020, 113-30; and Elaine Jeffreys and Su Gang, Governing HIV in China: Commercial Sex, Homosexuality and Rural-to-Urban Migration, Abingdon, UK and New York: Routledge, 2018.

15 Viviana A. Zelizer, The Purchase of Intimacy, Princeton, NJ: Princeton University Press, 2005, 15-16.

16 Eva Illouz, Cold Intimacies: The Making of Emotional Capitalism, Cambridge, UK: Polity Press, 2007.

17 Zelizer, The Purchase of Intimacy, 16.

18 Eva Illouz, Consuming the Romantic Utopia: Love and the Cultural Contradictions of Capitalism, Berkeley: University of California Press, 1997.

19 Arlie Russell Hochschild, The Commercialization of Intimate Life: Notes from Home and Work, Berkeley: University of California Press, 2003.

20 Wanning Sun, Inequality and culture: A new pathway to understanding social inequality, in Wanning Sun and Yingjie Guo (eds) Unequal China: The Political Economy and Cultural Politics of Inequality, Abingdon, UK and New York: Routledge, 2013, 27-42.

21 For example, Eva Illouz, Why Love Hurts: A Sociological Explanation, Cambridge, UK: Polity Press, 2012.

22 Judith Farquhar, Appetites: Food and Sex in Post-Socialist China, Durham, NC: Duke University Press, 2002, 24.

23 Ibid., 18.

24 Zelizer, The Purchase of Intimacy, 20.

25 富士康的夜生活 (Foxconn's night life), 13 September 2013, http://tech.sina.com.cn/it/2013-0913/09318736823.shtml, accessed 28 July 2020.

26 Yao Peng 姚鹏, 更值得䏌注的是女工的内心世界 (It is worth paying more attention to women workers' inner world), 中国妇女报 (China women’s news), 25 September 2013, A02.

27 For example, Mark Selden et al., Worker-intellectual unity: Suicide, trans-border sociological intervention, and the Foxconn-Apple connection, Asia-Pacific Journal 12(11), 2014, https://apjjf.org/2014/12/11/PunNgai/4093/article.html, accessed 28 August 2020.

28 Yan Dan 间丹 and Su Jianjun 苏建军, 在压力中成长在迷茫中坚守的富士康女 (Foxconn women maturing under pressure and persevering under disorientation), 中国妇女报 (China women’s news), 6 November 2013, A03.

29 Tao Haiqing 陶海青, 知音传媒上市前景几何? (What is the prospect of going public for Soulmate Media?), 中国贸易报 (China trade news), 12 June 2014, http://www.chinatradenews.com.cn/epaper/content/201406/12/content_17897.htm, accessed 9 September 2020.

30 Zhang Ning 张柠, 知音体与低端文化商品的生产和消费 (Soulmate genre and the production and consumption of low-end cultural products), 3 October 2013, http://blog.sina.com.cn/s/blog_a353266f0101rcrs.html, accessed 28 July 2020.

31 Aying 阿颖, ‘婚姻收购'传奇: 金钱直达哟爱情缓存 (A legend about a 'marriage for sale': Fast track to money while love awaits), 知音 (Soulmate), no. 12, 2014, 36.

32 Ibid., 37.

33 Illouz, Consuming the Romantic Utopia.

34 Arlie Russell Hochschild, The Managed Heart: Commercialization of Human Feeling, Berkeley: University of California Press, 1983.

35 Wang Shiyue 王十月, 出租屋里的磨刀声 (The sound of a cleaver sharpening in a rented room), 作品 (Literary works), no. 6, 2001, 4-10.

36 Du Ping 杜平, 男工·女工: 當代中國農民工的性別,家庭與遷移 (Male workers, female workers: Gender, family, and migration of contemporary Chinese rural migrant workers), Hong Kong: 香港中文大學出版社 (Chinese University of Hong Kong press), 2017.

37 Carolyn Cartier, Globalizing South China, Oxford: Blackwell, 2001. 
38 See Wanning Sun, Subaltern China: Rural Migrants, Media, and Cultural Practices, Lanham, MD: Rowman \& Littlefield, 2014.

39 For example, Liu, Wounded masculinities; Jeffreys and Su, Governing HIV in China; and Chris K. K. Tan and Zhiwei Xu, The 'social factory' of China's male 'virtual lovers', in Sun and Yang (eds) Love Stories in China, 168-84. Also see Tsang, Being bad to feel good.

40 You Fengwei 尤风伟, 泥鳅 (Loach), Shenyang: 春风文艺出版社 (Chunfeng literature and art publishing house), 2002.

41 Anne McClintock, Imperial Leather: Race, Gender and Sexuality in the Colonial Contest, Abingdon, UK and New York: Routledge, 1995.

42 Ibid., 6.

43 Pun Ngai, Made in China: Women Factory Workers in a Global Workplace, Durham, NC: Duke University Press, 2005.

$44 \mathrm{Du}$, 男工·女工.

45 Zelizer, The Purchase of Intimacy.

46 I am indebted to Meaghan Morris for suggesting this term. 